The cycle of erosion in different climates 



\section{Pierre Birot}

\section{The cycle of erosion in different climates}

Translated by C. IAN JACKSON and KEITH M. CLAYTON 
University of California Press

Berkeley and Los Angeles

First English Language Edition 1968

Published in Great Britain by B. T. Batsford Ltd

Originally published in Rio de Janeiro

under the title Le cycle d'trosion sous les differents climats

(C) Centro de Pesquisas de Geografia do Brasil,

Faculdade Nacional de Filosofia, University of Brazil, 1960

Library of Congress Catalog Card Number: 68-19704

Printed in Great Britain 